\title{
ALGUNAS CONSIDERACIONES SOBRE EL SIGNO ESPACIAL EN LA ESCRITURA AUTOBIOGRÁFICA
}

\section{Fernando Romera Galán}

\author{
Grupo de Investigación del SELITEN@T \\ fernandoromera@me.com
}

Resumen: En este trabajo se esboza un análisis de la importancia de algunas formas de presentación del signo espacial en la escritura autobiográfica, mostrando algunas características de este signo, especialmente en las formas barrocas que perviven en su expresión en dichos textos narrativos.

Abstract: In this work is outlined the importance of some forms of presentation of the spatial sign in the autobiographical writing, showing some characteristics of this sign, especially the baroques forms that survives in those narrativs texts.

Palabras clave: Signos. Espacio. Escritura autobiográfica. Écfrasis. España.

Key Words: Signs. Space. Autobiographical wryting. Ecfrasis. Spain. 


\section{DEL VIAJE A LA IDENTIDAD ESPACIAL: LA «CONDICIÓN VEGETAL» DEL HOMBRE}

En muchas ocasiones, la narración autobiográfica recoge las necesidades, las esperanzas o los deseos en forma de búsqueda de un espacio. Es habitual que coincida con memorias de juventud y que responda a la necesidad de exploración personal, asociados a lecturas o a viajes literarios. Por ejemplo, cuando el autobiógrafo termina sus estudios de Medicina y decide embarcarse hacia Cuba:

También yo estoy asqueado de la monotonía y acompasamiento de la vida vulgar. Me devora la sed insaciable de libertad y de emociones novísimas. Mi ideal es América, y singularmente la América tropical, jesa tierra de maravillas, tan celebrada por novelistas y poetas!... Sólo allí alcanza la vida su plena expansión y florecimiento (Ramón y Cajal, 1961: 203).

Estos cambios espaciales suelen coincidir con etapas de transición vital. A menudo es el lugar el que parece transformar al personaje que tiende a buscar una explicación en el espacio al que accede. Así, las descripciones suelen abundar en mayor medida, de manera que el lugar y el viaje tienen, a menudo, algo de ascético y de integrador en la vida adulta.

En principio, la aparición del espacio urbano dentro de los denominados libros de viajes, o crónicas de viajes, implica una visión subalterna del espacio, puesto que se plantea, no ya como un lugar propio, sino como una entidad comparativa. El viaje pone en contraste los espacios. Fernando Durán establece una premisa que nos parece interesante; a saber: cómo una autobiografía toma la forma de un libro de viajes y hasta qué punto esos mismos viajes no son sino un aspecto de la formación personal, de la configuración del yo que se nos va presentando en el texto:

Lo que me interesa destacar en estas páginas no es el tipo de libro de viajes que efectúa este autobiógrafo, sino el proceso mediante el cual un libro de viajes se convierte en un elemento definidor de una identidad individual: es decir, qué concepción del yo se deriva de una autobiografía que deviene libro de viajes (Durán, 1991: 75-88).

En el caso de la literatura española, podemos encontrar casos importantes. Las memorias de Dionisio Ridruejo (2007) se desarrollan, en buena parte, como la crónica de su desplazamiento por España durante y tras la Guerra Civil, de manera que, incluso los capítulos del libro en este apartado, llevan esos títulos: De Salamanca a Valladolid, De Madrid a Segovia... 
La ciudad se incorpora como referencia expresa en los escritos autobiográficos ya en la literatura del XVIII, como explica Fernando Durán:

También se ha hecho notar la facilidad con que tanto la autobiografía como el diario derivan en este periodo hacia el género viajero. $Y$ no se trata de una literatura de viajes centrada en lo pintoresco de las costumbres, en el color local o el paisaje: existe una marcadísima hegemonía del espacio urbano y además del espacio urbano desarrollado y civilizado, el que presenta una mayor riqueza intelectual y de trato social, porque estos hombres, al contrario que los románticos, no viajan para obtener emociones fuertes o tomar contacto con pasiones primitivas, sino para formarse y aprender (Durán, 1991: 84).

La vinculación de los textos autobiográficos a los espacios urbanos es, pues, antigua y relevante. Y no únicamente porque los autores viajaran, obviamente, sino porque el espacio urbano se había venido a convertir en una señal distintiva de cultura: son los comienzos del cosmopolitismo.

Este cosmopolitismo tendrá, a partir de ahora, un interés destacado, por cuanto no sólo hay que ser cosmopolita, sino demostrarlo públicamente; y una de las maneras es la demostración autobiográfica de los viajes. Entre las muchas razones que los autores dan para escribir una autobiografía está la de mostrarse públicamente, y esa exhibición pública de uno mismo requiere también la propia adjetivación, el propio lucimiento. Las ciudades visitadas, los viajes realizados se convierten en una marca personal, por lo que el autor va a seleccionar cuidadosamente qué lugares pretende enseñar en los textos. No es un problema de veracidad, en este caso, sino de cómo es capaz un autor de mostrarse en público.

Venimos hablando de la importancia que tiene el viaje y la educación personal en la literatura del siglo XVIII. Pero no sólo es importante este aspecto en la literatura neoclásica, sino que llega hasta bien entrado el siglo Xx. Muchas autobiografías, literarias o no, redundan en el aspecto de la evolución cultural y educativa personal. Así, autores que han hecho de la cultura el vehículo o hilo conductor de una vida, redundan en este aspecto y, significativamente, también hacen hincapié en todos los viajes y desplazamientos que se han dado en su vida. Hemos propuesto el ejemplo de Ramón y Cajal, quien, en la práctica totalidad de los capítulos que ocupan su autobiografía, refleja, junto con otros aspectos de su vida, el viaje en el que se encierra esa etapa o momento de su vida. (1961: 26-153). Así: Mi estancia en Valpalmas; Mi traslación a Jaca; Dispone mi padre llevarme a Huesca para continuar mis estudios; el Ebro y sus alamedas; Me embarco en Cádiz con rumbo a la Habana. 
Estos viajes de erudición o de formación son comunes. Galdós también señala en sus memorias su orgullo por ser el único español que parece haber visitado la tumba de Shakespeare. Esta suerte de narcisismo viajero es más habitual de lo que parece y, en cuanto al género autobiográfico, mantiene la necesidad del autor por elevarse literariamente:

Creo que soy de los pocos, si no el único español, que ha visitado aquella Jerusalén literaria y no ocultaré que me siento orgulloso de haber rendido este homenaje al altísimo poeta cuyas creaciones pertenecen al mundo entero y al patrimonio artístico de la humanidad (Galdós, 1975: 153).

Por lo tanto, podemos evidenciar que el autor de autobiografías tiende, en muchas ocasiones, a uno u otro espacio vital. Bien sea la ciudad, bien el campo, los pueblos pequeños, las grandes urbes... el lugar se presenta, muchas veces, en los textos autobiográficos como una tendencia personal que refleja las necesidades y los gustos del autor. Es decir, existe una identificación íntima entre espacio y protagonista, lo que nos lleva a pensar en una vinculación metonímica entre espacio y autor.

Vinculación que se acentúa desde el discurso autobiográfico de la vejez. La imagen personal de una vida cumplida busca contemplar el espacio como una tendencia necesaria. Proponemos el ejemplo de Miguel Delibes, bien estudiado, entre otros, por Romera Castillo (1992), quien ve intensificada su relación con su ciudad natal con Valladolid cuando llega al final de su carrera literaria:

He aquí un hecho cierto: cuando yo tomé la decisión de escribir, la literatura y el sentimiento de mi tierra se imbricaron. Valladolid y Castilla serían el fondo y el motivo de mis libros en el futuro. Pero semejante decisión no implica que Valladolid y Castilla me deban algo, sino, al contrario, soy yo el que me siento deudor, porque de ellos he tomado no sólo los personajes, escenarios y argumentos de mis novelas, sino también las palabras con que han sido escritas (Delibes, 1996: 199).

Podemos extraer varias consecuencias de los textos de Delibes. En primer lugar, que el espacio sufre un proceso de personalización (no de personificación, o al menos, no únicamente). La ciudad es el espacio y las gentes con todo lo que ello conlleva: lugares, personas, lengua, usos de habla... Los recuerdos se convierten en la imaginería de la escritura, pero también la vinculación a través del habla de esa ciudad. Delibes recuerda pero también hace presente el espacio a través de la forma del castellano de Valladolid. Las imágenes son de escenarios, descripciones espaciales, pero 
el germen de la literatura también es el recuerdo de cómo se hablaba en esos lugares:

En Valladolid aprendí a hablar, en aquel Valladolid del tren burra y los amarillos tranvías con jardinera, de los pregones en las viejas rúas y los charlatanes en la Plaza Mayor, de la hermana Remedios en las Carmelitas del Campo Grande, y el hermano Enrique en el colegio de Lourdes... Aquellas voces que arrullaron mi infancia fueron el germen de mi expresión futura (Delibes, 1996: 199).

Es lo que Delibes reconoce con el nombre de «condición vegetal» y que hemos reproducido como título de este epígrafe. Condición que viene dada por una especie de sentimiento de arraigo contraída por el nacimiento y el paso de los años y que se convierte en un vínculo de vida. El propio espacio se convertirá en esa colección de imágenes que va a ser precisa para abordar la creación literaria; es decir, tarde o temprano esa espacialización va a ir apareciendo en los textos que el autor produzca. Lo explica de la siguiente manera:

A mí me nacieron aquí, en la vallisoletana Acera de Recoletos, y aquí arraigué en poco tiempo tan profundamente que ya de niño, trasladarme a otro lugar hubiera comportado un desgarramiento, el dolor y los riesgos que lleva consigo todo trasplante. Sencillamente estoy aquí, sigo aquí, porque no me hubiera acertado a estar en otra parte, porque sin este cepellón de tierra bajo mis pies, me hubieran faltado nutrientes y tal vez mi imaginación se hubiera esterilizado (Delibes, 1996: 200).

El pensamiento de Delibes sobre estas condiciones espaciales de la vida tiene ciertas resonancias orteguianas y viene a explicar cómo las circunstancias vitales pueden ser, precisamente, las vivencias del espacio urbano: «la circunstancia de que habló Ortega era para mí Valladolid» (Delibes, 1996: 201).

Y, como venimos explicando, esta relación personal con la ciudad se produce a través de los otros: la familia, los amigos, las instituciones... Esa individuación espacial es la que da lugar a la expresión «mi ciudad» que encierra no sólo una connotación puramente posesiva o de relación causal, sino una relación afectiva. En el caso de las referencias a la ciudad propia el adjetivo posesivo suele tener, a menudo, ese matiz semántico afectivo:

Ahora se dice de estos sentimientos que son viscerales. Yo ceñiría un poco más este adjetivo: diría que son cordiales. Porque a esas alturas de la vida a las raíces iniciales que me ataban a mi ciudad, había que ir añadiendo otras nuevas de las que nunca podría ya desasirme: mis queridos muertos, mi familia, mis amigos, mi Norte de Castilla, mi Escuela de Comercio, mis calles 
de todos los días, mis campesinos, mi tierra... Podrían existir otros amigos, acaso otros periódicos, otras Universidades, otros campesinos, otras tierras sin duda, pero nunca serían lo mismo (Delibes, 1996: 201).

Podemos esbozar, por lo tanto, que ese sentimiento de arraigo es una de las bases para la aparición de ciertas formas de expresión escrita autobiográfica. Los casos que hemos visto aportan una visión de cómo el lugar de nacimiento o de desarrollo se incorporan a la propia vida de manera que la formulación de este espacio en la escritura se hace imprescindible y se connota de manera notable.

\section{EL ESPACIO PERSONIFICADO Y LA FICCIÓN}

De esta manera, ciudad y protagonista, a menudo, se sienten identificados. Una de las apariciones habituales de la ciudad en los textos autobiográficos es la del espacio personificado. La ciudad representa, no a sí misma, sino a sus habitantes o sus gentes. A menudo, incluso el autor puede referirse a ella de manera personal, reflejada en una especie de personaje que pulula por las páginas del texto. Esto es lo que hace Galdós en sus memorias:

¿Qué tendrá Madrid, que está tan cabizbajo y cariacontecido? Parece que una gran desgracia le amarga, o que una nube siniestra, preñada de tempestades, amenaza con descargar sobre su cabeza todo un arsenal de rayos, centellas y demás proyectiles atmosféricos (Galdós, 1975: 35).

Esta manera de reflejar la identidad de la ciudad se da en mayor medida cuanto mayor es la relación personal y de conocimiento que el autor posee. El caso de Galdós es significativo porque su vida en Madrid fue, también, generadora de espacios novelísticos. Esta relación personal con la ciudad es tan profunda que no duda en referirse a ella de la siguiente manera: «Todas las funciones orgánicas de ese señor grave y juicioso que se llama Madrid están alteradas» (Galdós, 1975: 36).

Este extremo de identificación es común entre la autobiografía y la novela. Por ello, suele ocurrir el proceso contrario, el de cosificación. Dionisio Ridruejo, en sus memorias recientemente publicadas, explica esto mismo refiriéndose a Madrid:

Bueno; aquello era un Madrid escenario, o más bien un Madrid cosa y no propiamente un Madrid pueblo, si se salvan las tres o cuatro referencias sociales a las que acabo de aludir (Ridruejo, 2007: 111). 
Sin embargo, la cuestión de la relación entre el personaje y el espacio urbano no es baladí. En el caso de las memorias, la ciudad tiende a aparecer desdibujada en muchas ocasiones y perfectamente descrita en otras. La cuestión de la memoria hace que no exista mucha diferencia entre el signo en la novela y estas memorias, puesto que esos fallos en el proceso de recuerdo tienden a rellenarse de forma ficcional. Volviendo a Ridruejo, la recreación de algunos espacios urbanos se ve teñida de una ficción involuntaria:

Nos alojamos en un hotelito de categoría media que estaba y seguramente sigue, en la plaza Mayor: El hotel Victoria. Recuerdo un comedor abovedado, con pinturas. El balcón de nuestro cuarto daba a la calle enfrente de la iglesia de San Miguel. ¿Es verdad que vi el incendio que se comió la cubierta de esa iglesia y consumió buena parte de su tesoro interior? [...] Si no es real este recuerdo, será que se han superpuesto las imágenes (Ridruejo, 2007: 99).

Pero, lo que es más, incluso en los casos en que esto es fácilmente verificable, el propio autor reniega de esta posibilidad para dejar la ficción fluir en el texto:

Para ponerlo en claro me bastaría leer la crónica local. No merece la pena. En mi memoria están los tizones volantes, el toque de las campanas a rebato y el crecimiento de las llamas (Ridruejo, 2007: 99-100).

Luego, la relación memorística de los hechos narrados no supone su certeza; es más, incluso esta certeza es, a menudo, rechazada por motivos más o menos sentimentales.

\section{LA PEQUEÑA CIUDAD RECIÉN NACIDA: EL CAMPO Y LA CIUDAD}

Es habitual, y depende de innumerables factores que van desde la perspectiva personal a las modas estéticas literarias, la aparición de la dialéctica entre el campo y la ciudad. Si seguimos con Ridruejo, la permanente referencia a Madrid y la capitulación de las memorias en puros viajes de ciudad en ciudad, se rompe, sin embargo, con su declaración acerca de Ronda: «La tierra es inagotable y nada alimenta tanto la imaginación como verla cambiar con las estaciones. (Por eso en las ciudades me seco)» (Ridruejo, 2007: 407).

En la tradición autobiográfica, podemos encontrar la dualidad campo-ciudad en muchas ocasiones. 
Baroja reconocía que sólo a principios del xx comenzaba a darse:

un deseo relativo de conocer la tierra donde se vive y cierto afán por viajar; no hay ese prestigio único de París, y se siente afición al campo, a las excursiones, a los viajes pequeños y a las ciudades de provincia (Baroja, 1997: 650).

Los diecisiete tomos que completan, hasta hoy, los diarios de Andrés Trapiello (1990-2007) son también un buen ejemplo de cómo se trata, hoy en día, esa oposición representada por sus estancias en Extremadura, pintada como una suerte de paraíso rural, frente a la ciudad de Madrid, que no está, sin embargo, teñida de matices o connotaciones negativas.

Parece obvio sospechar que esa contraposición comienza en el momento en el que la ciudad empieza a ganar protagonismo en la vida intelectual y afectiva de sus habitantes. Y esto comienza a suceder en el siglo XIX, fundamentalmente, aunque ya apunta esta tendencia en los ilustrados del XVIII. Cuando Julián del Casal escribe la siguiente carta no está dando una opinión personal sobre la vida en el campo, sino una presuposición estética derivada de la influencia que la gran ciudad ha ejercido sobre él y su vida libresca:

Hace unos días que llegué del campo y no había querido escribirle porque traje de allí muy malas impresiones. Se necesita ser muy feliz, tener el espíritu muy lleno de satisfacciones para no sentir el hastío más insoportable a la vista de un cielo siempre azul, encima de un campo siempre verde. La unión eterna de estos dos colores produce la impresión más antiestética que se pueda sentir (Casal, 1982: 82).

Es a partir de los movimientos y las actitudes finiseculares (el propio Julián del Casal, los poetas malditos, la bohemia de las grandes ciudades...) cuando la ciudad comienza a tener espíritu, o, en palabras de Borges, «autobiografía»:

Yo afirmo que solamente los países nuevos tienen pasado, es decir, recuerdo autobiográfico de él; es decir tienen historia viva. Yo no he sentido el liviano tiempo en Granada, a la sombra de torres cientos de veces más antiguas que las higueras y sí en Pampa y Triunvirato, insípido lugar de tejas anglizantes ahora, de hornos humanos de ladrillo hace tres años (Borges, 1963: 131-132).

Y comienza a definirse por oposición al campo, por oposición a las pretendidas esencias estéticas y espirituales que la vida rural venía trayendo desde la tópica y la retórica clásica que se perpetúa en el Beatus Ille horaciano, todo el Siglo de Oro español, el siglo XVIII, etc. 
Podemos pensar, pues, que es en el siglo XIX cuando se modifica este sentimiento y se convierte en oposición. No es ya posible considerar una compatibilidad entre campo y ciudad, sino es como una concepción histórica, como un recuerdo de la pasada belleza, como una imagen de la muerte. Y ha de ser por esta razón por la que los autores simbolistas verán integrarse ambas en las pequeñas ciudades frente a las grandes capitales, los que entenderán que el viejo concepto de ciudad está muerto, que los conceptos sociales burgueses que habían dado lugar al viejo espacio urbano ya, simplemente, no existían. Si la ciudad se había comportado como una suma de intereses sociales establecidos en clases, donde cada uno tenía su lugar asignado históricamente, la nueva ciudad emerge como una oportunidad estética, como un verdadero «espacio» que puede ser modificado y recreado sobre unos conceptos éticos nuevos. Álvaro Salvador (2007: 19) ha recogido el verso de Julián del Casal para dar título a su libro El impuro amor de las ciudades, en el que explica que «el espacio urbano es uno de los ingredientes más novedosos y decisivos que la modernidad introduce en la lógica interna de la literatura y el arte finiseculares».

La ruptura con la vieja ciudad será experimentada en el nuevo urbanismo y abrirá la puerta a un nuevo modo de ver y vivir el espacio del entorno: la mirada del denominado flâneur, cuya primera experiencia vendrá de la mano - del ojo - de Baudelaire. Sobre este punto, Álvaro Salvador opina lo siguiente:

La revolución experimentada por las ciudades europeas e hispanoamericanas a finales de siglo, según el modelo que proporcionó Haussmann y sus reformas en el centro de París, demoliendo la ciudad medieval y abriendo grandes redes viarias en forma de bulevares, supondrá una nueva geografía para la mirada atenta del artista y un nuevo lugar de relaciones - asimismo nuevaspara su capacidad de percepción e interpretación del mundo exterior (Salvador, 2007: 29).

Y si esta repercusión será grande para la poesía o la novela, igualmente importante, si no más, lo será para la escritura autobiográfica por cuanto estas modalidades reflejarán con especial énfasis la importancia que tiene el nuevo espacio recién nacido para el autor y su obra.

Georg Simmel (1986) explica el cambio de mentalidad que se produce en la sociedad del siglo XIX en torno a las transformaciones urbanas y la oposición a la ciudad. Ve en las grandes ciudades europeas (fundamentalmente en Berlín) la nueva forma de organización que marcaría los procesos sociales durante y tras el fenómeno de la industrialización. Destaca las distincio- 
nes entre campo y ciudad como los elementos en torno a los que se habían venido estableciendo las descripciones de los dos modelos de sociedad que se corresponderían con formas contrapuestas de organización. Las grandes ciudades se opondrían a las ciudades más pequeñas que, durante el siglo XIX - y en el siglo XX aún en España - mantendrían formas de organización «comunales». Conceptos como anonimato, individualización, libertad, secreto, superficialidad... se le irán añadiendo a las connotaciones urbanas frente a las formas de organización rurales. Y, por lo que interesa a nuestro estudio, es interesante destacar cómo ese concepto de anonimato y secretismo irá organizando el pensamiento de los autores del XIX, de manera que la gran ciudad será percibida, paradójicamente, como el modelo de espacio íntimo. Porque las repercusiones que tiene el anonimato en la gran ciudad son absolutamente diferentes que las relaciones que se producen en la ciudad pequeña:

La actitud de los urbanitas entre sí puede caracterizarse desde una perspectiva formal como de reserva. Si al contacto constantemente externo con innumerables personas debieran responder tantas reacciones internas como en la pequeña ciudad, en las que se conoce a todo el mundo con el que se tropieza y se tiene una relación positiva con cada uno, entonces uno se atomizaría internamente por completo y caería en una constitución anímica completamente inimaginable. En parte esta circunstancia psicológica, en parte el derecho a la desconfianza que tenemos frente a los elementos de la vida de la gran ciudad que nos rozan ligeramente en efímero contacto, nos obligan a esta reserva (Simmel, 1986: 253).

Por lo tanto, puede parecer extraño que la gran ciudad haya generado interés autobiográfico como espacio de lo autónomo y lo personal, cuando, en realidad, es el verdadero lugar de reflexión interior y de espacio de intimidad.

¿Sería pensable una narración auténticamente autobiográfica en el marco de las relaciones sociales de una ciudad pequeña? De hecho y, con respecto a este último extremo, podemos acercarnos a un buen número de casos en los que ha dado lugar a novelas en clave o narraciones más o menos crípticas en las que se puede distinguir material autobiográfico tras el disfraz de los pseudónimos o la modificación de los lugares. Este es el caso, por ejemplo, de la novela de Óscar Esquivias (2000), El suelo bendito, en donde se plasma la ciudad de Burgos y algunos de sus personajes, bajo apariencias que permiten intuir la vida y pecados de la ciudad y sus ciudadanos, pero que impide percibirla como una auténtica narración autobiográfica. Si el autor se siente comprometido en la historia de manera que esa implicación pueda 
romper el equilibrio social de una sociedad tradicional, la autobiografía se camufla bajo otras apariencias. La gran ciudad, ocultando al autor en la multitud, favorece la materia autobiográfica.

\section{LA AUTOBIOGRAFÍA ES UNA ÉCFRASIS Y EL ESPACIO HA VENCIDO A LA PALABRA}

En un sentido amplio podemos definir la écfrasis como una formulación verbal de una representación visual. El espacio va a aparecer definido por su exclusión, por la intrusión de un segundo lugar que media entre autor y ese mismo espacio.

En la autobiografía pasa algo parecido y son muchas las modalidades autobiográficas en las que el ejercicio ecfrásico recupera las imágenes para convertirlas en un juego verbalizado, en el que las sensaciones, las impresiones nos vienen de segunda mano, de segunda mirada. Hay algún ejemplo de ello. Nabokov en Speak, Memory (1951), que podemos considerar como una novela autobiográfica $\mathrm{o}$, al menos, de corte autobiográfico, imagina entrar en un cuadro. Estas rupturas semióticas son habituales en otras artes como el cine y podemos recordar La rosa púrpura del Cairo, de Woody Allen, en la que el protagonista sale de la pantalla. No son rupturas narrativas, sino rupturas semióticas y ontológicas. El recuerdo de una fotografía antigua no proporciona un elemento de recuperación de la memoria, sino una reconstrucción de un espacio a través de ella, una ruptura del marco semiótico de la narración autobiográfica, mediante el cual se rompe el proceso de representación de la realidad: la fotografía es real, pertenece a nuestro mundo, pero la descripción autobiográfica a partir de ella convierte lo narrado en ficcional por la ruptura de ese marco semiótico y ontológico.

En estricto sentido, algunas autobiografías recurren a estas rupturas ecfrásicas para reflejar cómo era el autor en la época pasada. Un buen ejemplo es el de González Ruano:

Tengo un retrato de entonces, de cuando podría yo tener eso: diecisiete o dieciocho años. Por detrás, el retrato está apasionadamente, ingenuamente dedicado a una mujer. Esa mujer me lo debió de devolver con mis cartas. Mi madre guardaba el retrato y me lo ha dejado. ¿Ese barbilindo soy yo? (González Ruano, 1979: 89).

En este texto, bajo el expresivo título «Epílogo del primer tiempo ante un retrato de entonces», modifica incluso el marco narrativo al devolverle al re- 
tratado la tercera persona y convertir al yo en otro, de manera que el autor se distancia de sí mismo a partir de la écfrasis:

Sin embargo, este muchacho, aunque desordenadamente, leía. Leía todo cuanto caía en sus manos, comprado, prestado o afanado [...]. Y este muchacho, por sendas no muy profundas, sino estrictamente literarias, leyó las Memorias del Marqués de Bradomín (González Ruano, 1979: 89).

Queremos decir, con todo esto, que la mirada hacia uno mismo puede realizarse a través de procedimientos de écfrasis, de relato verbal de la imagen. Porque la forma de mirar, que ha caracterizado a una determinada época, ha explicado los valores tradicionales de ese momento. La écfrasis se vincula a un modo barroco de entender la realidad y los poemas ecfrásicos, como una de las características de la poesía del siglo XVII, aunque sea también abundante durante la poesía del siglo Xx, en poemas, por ejemplo, de Guillermo Carnero o Luis Antonio de Villena.

Las modalidades autobiográficas suelen, pues, recurrir a intermediarios visuales y cabría preguntarse, en último extremo, si no sucede el fenómeno de que toda autobiografía sea una concepción verbal de una serie de imágenes reflejadas en la memoria. Un buen número de poemas de corte autobiográfico inciden también en ello. Pero cabe preguntarse hasta qué punto de la hiperestesia visual comporta ese barroquismo vacío. Hay quienes han anunciado el fin de la poesía en la forma en que la conocemos: en un lenguaje de palabra débil, de significantes vacíos que no remiten a nada que pueda ser concretado convencionalmente, la poesía se ha cerrado en fórmulas caducas que se repiten hasta la saciedad. Poetas locales, que no contemplan el final de la palabra en su formulación lírica, se empeñan en repetir tópicos de belleza que a nadie le explican un mundo conocido. El discurso metafísico, la formulación de lo espiritual, de la definición ontológica de la belleza como «reflejo de lo perfecto» nos dejan hoy fríos. La identidad del autor ha quedado expuesta a esta debilidad lírica que no es capaz ya de hacernos ver la intimidad y la reflexión sobre el mundo. Los poetas se afanan por incorporarse a la vieja guardia de vates que, a la manera romántica, buscan la gloria y la inmortalidad, cuando la primera se ha convertido en un mundo efímero vinculado a la velocidad de los cambios comunicativos, y la segunda ha desaparecido, directamente, de la epistemología contemporánea. Estas ideas son mantenidas por Fernando Rodríguez de la Flor en su interesante ensayo Biblioclasmo. Por una práctica crítica de la lecto-escritura. La poesía haría cobrar un especial sentido al mundo, sentido que se habría perdido en la actualidad: 
La poesía, por su parte, ha sido, en realidad, una estructura que, bajo el auxilio medial del lenguaje y del dispositivo retórico, hace cobrar (un) sentido a la realidad ya transcurrida o bien imposible, soñada. Pero por lo que sabemos de esta operación, al tiempo mismo que en ella algo queda revelado para la conciencia, queda también destituido como excluido de la corriente del tiempo y del espacio, de la vida en sí (Rodríguez de la Flor, 1997: 218).

La poesía tendría, pues, cierta gradualidad de evanescencia de la realidad $\mathrm{y}$, por lo tanto, una capacidad de trabajo en la memoria, por lo que tenderíamos a involucrarla en los terrenos del subjetivismo y de la apertura a la interpretación.

Pero si, dicho todo lo cual, entendemos que esa modalidad subjetiva está en trance de desaparición, si la consideración de la lírica es imposible con un lenguaje feble o debilitado, si el espacio ha sido, igualmente, desvinculado de la poesía, como la propia vida, ¿podemos explicar, a raíz de ello, la generalización de la materia memorialística como fórmula que consigne ese mundo que la poesía ya no es capaz de nombrar? ¿Cómo se explica, entonces, la reafirmación de los géneros autobiográficos como los diarios o las memorias? La vinculación de la poesía y el mundo, según Rodríguez de la Flor, se daba a través de los procedimientos retóricos que permitían hacerle cobrar sentido, o, al menos, un nuevo sentido no conocido. Por decirlo de alguna manera, aunque seamos capaces de mirar al mundo, somos incapaces de nombrarlo y Wittgenstein tenía razón al decir que nuestro mundo está limitado por nuestro lenguaje.

Quizá haya que explicar que uno de los cambios que se ha operado en nuestra concepción del mundo es el de la mirada en torno. Históricamente, se ha comprobado que el cambio fundamental que se da en el paso de la Edad Media al Renacimiento es, precisamente, la aparición de la perspectiva en el arte pictórico. Lo que había sido representación multidireccional, en la que muchas formas de contemplar y puntos de contemplación se superponían, se convierte en la dirección obligada a un punto físico, dirigido por el autor que impedía la personalización, la subjetividad pública. El pintor queda reducido a un ojo único que también diluye al espectador en la obra. Esto llegará, claro está, casi hasta nuestra edad contemporánea, intensificado por la visión monocéntrica cartesiana que enfoca el mundo todo en la visión y explicación interior.

Quizá sólo sea la estética barroca la que rompe esta tendencia a base del exceso, mediante la acumulación y la búsqueda de una mirada «frágil». Como señala Martín-Estudillo: 
Estamos ante la vindicación de una mirada frágil [...], descentrada, barroca, en definitiva, que supone una alternativa a la mirada fuerte, presuntamente natural y acorpórea del perspectivismo cartesiano (Martín-Estudillo, 2007: 145).

La contemplación de la perspectiva se filtrará a otras concepciones y convenciones sociales. La ciencia, la literatura... no resistirán la llegada del nuevo método. La mirada del espacio circundante se convertirá en la nueva manera de explicar el mundo.

Mieke Bal (1997), siguiendo las teorías de Norman Bryson (1983), explica la visualidad en torno a dos expresiones que nos definen sendas maneras de mirar el mundo. Una primera forma, sería aquella en la que se da un ocultamiento de quien mira y supone una naturalización en la forma de presentar la mímesis. Esta forma es denominada como «gaze». La otra opción, es la de aquel que sí interviene y actúa de mediador entre el mundo y aquel a quien se le relata, que recibe el nombre de «glance». Los procedimientos ecfrásicos no están, necesariamente, circunscritos a uno de los dos medios de explicación visual, aunque tendemos más a distinguir fórmulas de «gaze» en ellos, por lo que supone de intercepción de un medio entre el contempladortransmisor y el mundo. Pero no siempre es así, porque ningún tipo de mirada es totalmente aséptica, ni siquiera la que pretende no intervenir en el mundo y se quiere limitar sólo a transmitir objetivamente desde su puesto de observador, una presentación natural de la mímesis.

En una narración de cualquier tipo, incluida la autobiográfica, la percepción espacial viene dada por cualquiera de las dos perspectivas. La narración ficcional parecería mostrar el mundo desde una mirada átona, no involucrada. Pero no es cierto. Ni siquiera la poesía tiene esa concepción más subjetiva y menos atenuada de la presencia autorial, pues incluso en ella podemos apreciar procedimientos ecfrásicos que diluyen al autor, por no hablar del ya mencionado desenfoque barroco de la perspectiva tradicional. Incluso, yendo mucho más allá en nuestras apreciaciones, podemos considerar que la poesía contemporánea ha abandonado las perspectivas tradicionales para ni siquiera saber interpretar lo que ve. Fernando Rodríguez de la Flor, apocalíptico en su percepción, pero afinado en su análisis, expresa esta primacía de la contemplación frente a la creación poética, de manera que los dominios de la poesía han quedado libres para otros géneros, o simplemente olvidados para el mundo de la creación artística:

Reintegrado al dominio de lo real, de lo espectacular y aun masificado, el poeta, con su trabajo, (re)produce, pero ya no crea. Llevado de la mala 
conciencia de venir a ser el agente de una pérdida, el lugar donde se señala un déficit, el artista verbal agita hoy todavía un jirón de su bandera metafísica [...]. Todo en vano, su voz es absorbida, reconducida hacia una suerte de espacio espectacular, de escena de representación donde desempeña, junto con otros lenguajes técnicos de rara proveniencia -espiritismos, legiferaciones, desechos de lenguajes ritualizados, latines papales...-, un papel predeterminado en la economía discursiva (Rodríguez de la Flor, 1997: 146).

Perdida la autoridad del poeta para dar al lector un asidero ontológico y metafísico, y, cuando la novela está derivando a una suerte de mercantilismo donde la escritura pseudo-historicista aporta escasa relevancia literaria al discurso, la autobiografía está adquiriendo un valor sólido merced a ese pacto lejeuniano que nos lleva a identificar al autor con el narrador y con el personaje y a todos ellos con el mundo narrado. El espacio en la autobiografía se presenta con una autoridad que no es capaz de dar la lírica que ha dejado de fundar simbólicamente «otros mundos».

Por otro lado, hay una diferencia textual que afecta a la autobiografía y no a otros procesos narrativos, como la novela o el cuento. Podemos asegurar con cierta claridad que la materia sobre la que trabajan los textos (aparentemente) de ficción sería la imaginación, mientras que los materiales con los que se construye una autobiografía o un texto de carácter autobiográfico es la memoria. En un texto de ficción no se explicita en ningún momento ese material, sino que la narración fluye como si el texto fuera dictado directamente por la historia narrada. Sin embargo, en un texto autobiográfico suele explicitarse siempre la referencia a la memoria como generadora del texto, de la palabra escrita. Y esta memoria suele aparecerse en forma de imágenes, de manera que el texto opera sobre una serie de imágenes ya fijadas, a la manera de textos icónicos que están por desentrañar y que se presentan como imágenes brumosas. Son muchos los textos memorialísticos que podemos aportar como ejemplo. Luis Antonio de Villena recuerda sus años de infancia como imágenes a través de la niebla:

Me parece recordar - la angustia también es brumosa o crea bruma-que para que los padres tuvieran una primera idea de lo que era un campamento de la OJE (o llanamente porque se hacía así) nos mandaron formar en la explanada de la estación (Villena, 2004: 15).

Y casi como cierre del libro se reúnen visión e imaginación en una única expresión de certeza autobiográfica: 
Vida extraña que te vemos ser y existir en nosotros, pero que te escapas sin hacerte. ¿Si te sentimos real, pues te vemos e imaginamos, quién o quiénes hacen que no te atrapemos nunca? (Villena, 2004: 252).

Quizá una de las expresiones más brillantes a este respecto aparece en los diarios del húngaro Imre Kertész, quien define esas imágenes de la memoria como una metáfora:

Los recuerdos son como perros abandonados, vagabundos, nos rodean, nos miran, jadean, aúllan alzando la vista a la luna; querrías ahuyentarlos, pero no se marchan, te lamen ávidamente la mano, y cuando les das la espalda, te muerden... [...] Las imágenes del verano pasado parecen apuntes escritos en las hojas que caen de los árboles y revolotean ante mi ventana impulsadas por el viento (Kertész, 2002: 101).

Las diferentes modalidades autobiográficas están recomponiendo un éxito insospechado porque todos somos capaces de comprender, en nuestro propio imaginario vital, que todo recuerdo es, en sustancia, un álbum de imágenes, «un montón de imágenes rotas en las que da el sol», como decía T. S. Elliot. Y entra dentro de nuestro modo contemporáneo y posmoderno de acercarnos a la comprensión de nuestro mundo, icónico y visual, frente a la pura palabra, y acceden a nosotros a la manera de representaciones ya trabajadas por la particular retórica de la memoria y el olvido, es decir, de la ficción. Por ello, toda autobiografía es una construcción ecfrásica.

Pongamos el ejemplo de Caballero Bonald, que abre Tiempo de guerras perdidas buscando el imaginario de la infancia a través de una estampa visual:

Las fronteras de la infancia suelen coincidir con las del verano. Yo, al menos, nunca he logrado situarlas de otra manera en el territorio general de la memoria, como si lo más notable que me hubiese ocurrido cuando era niño permaneciera enmarcado en un campo estival o en una playa radiante de la Andalucía atlántica o en los tórridos atajos callejeros de Jerez. Las otras imágenes infantiles, por muy copiosas que sean, perseveran en la evocación dentro de un relieve mucho más desviado y una tonalidad muchos menos acusada (Caballero Bonald, 1995: 7).

Las diferentes modalidades autobiográficas son capaces de fundamentar el mundo que el lector busca en la narración, porque es capaz de aportar un trasfondo de aparente verdad. Pero también, porque el autor habla desde la experiencia de lo vivido, y el lenguaje parece haber instituido una fortaleza 
de la que carecen otras expresiones verbales. La experiencia del mundo se narra con autoridad física y evita la expresión autónoma, desvinculada de asideros de verosimilitud. Incluso aquellos textos de tono o carácter autobiográfico que pretenden adentrarse en los terrenos de una experiencia metafísica o religiosa, más o menos profunda, vienen precedidos de la autoridad de una vida marcada por el éxito literario, académico o, simplemente, personal.

\section{LA CIUDAD RETÓRICA: TOPOGRAFÍAS DEL VACÍO}

Es a partir del siglo XVII y la consideración del vacío como entidad física a tener en cuenta, cuando el hombre barroco acepta la posibilidad de un futuro muerto o inconsistente. El horror vacui, la vanitas, el memento mori... no son sólo recuperaciones de tópicos clásicos, sino reflejo de la percepción negativa que el tiempo y el futuro engendran en el pensamiento de la época.

Y hay síntomas en la escritura autobiográfica de esa idea barroca de la vaciedad de la vida, una sensación contemporánea de que toda construcción (humana o divina) es sólo la expresión de esa necesidad de llenar los espacios. Imre Kertész, en sus diarios Yo, otro, lo explica así:

Si el vacío (mi vacío interior) provoca un sentimiento de culpa, tal vez me permita sacar conclusiones respecto a lo que es el origen. La angustia precedió a la creación: el horror vacui es un hecho ético (Kertész, 2002: 7).

Y para Kertész, la esencia de esa descomposición urbana que no es sino su visión barroca de la ciudad, son las ciudades de Alemania, Munich, Berlín, que, tras la tragedia del nazismo, han resurgido a la manera de un espacio recargado y fútil:

Paseo por Munich. Busco el célebre barrio de Schwabing. No existe; mejor dicho, lo que existe no es eso [...]. Alemania ha quedado devastada tras la sentencia divina. Estas ciudades, estas calles, todos estos edificios nuevos o reconstruidos parecen la piel cicatrizada de una enorme herida. Nadie lo sabe, y lo consideran bonito (Kertész, 2002: 41).

Luis Martín-Estudillo encuentra, además, la vinculación de los temas barrocos con la poesía española contemporánea, sobre todo en las obras de algunos autores como Guillermo Carnero o Luis Antonio de Villena. Para Martín-Estudillo, la posmodernidad recoge esa tradición del horror al vacío por cuanto define un mundo de significantes que no están hilvanados con un referente: 
Existe la percepción de que la posmodernidad es un contexto saturado por significantes que han perdido su conexión con sus referentes (esa separación entre «las palabras y las cosas» que Foucault percibía en el Barroco), unos referentes que se tornan espectáculo omnipresente, haciendo de nuevo pertinente una reflexión sobre cierto horror al vacío (Martín-Estudillo, 2007: 106).

Podemos considerar, después de lo expuesto, que el Barroco es, con todo, el momento en el que la identificación del yo con el espacio es más intensa, desde el momento en que el entorno que es habitado remite necesariamente a las preocupaciones existenciales que el autor trata de exponer. La mirada que escruta el espacio es, finalmente, una mirada hacia el interior que devuelve la miseria del paso del tiempo y la vanidad del mundo. En palabras de Quevedo: «Y no hallé cosa en que poner los ojos / que no fuera recuerdo de la muerte». Topografía, bien es cierto, que está influida por el no espacio, por la idea de un lugar que no es lugar, que se muestra carente de sentido por cuanto es caduco e insustancial. Los cuadros de vanitas, bodegones, los still life son, pues, reseñas de un espacio que, en último extremo, es la rememoración de la vida propia.

$\mathrm{El}$ «vivir en muerte» barroco o el vivir sub specie mortis, lleva a una pulsión memorística que implica el recuerdo de detalles nimios, la mayoría de ellos de tipo topográfico: nombres de calles, lugares descritos con absoluto detalle, descripciones fotográficas de la casa, la habitación... como un deseo de plasmar con exactitud absoluta la vida, como explica Celia Fernández Prieto:

El narrador, precavido ante las asechanzas de la ficción, somete el discurso a una estricta disciplina, intentando eliminar todo cuanto pudiera enturbiar la ilusión de la transparencia. Lograr el grado cero de la escritura. El máximo de legibilidad. Sin literatura. Prosa quirúrgica, anatómica, denominativa, topográfica, llena de instrucciones referenciales (Fernández Prieto, 2005: 51).

La necesidad de arraigo es casi siempre de arraigo a un lugar, a una ciudad, a una casa y la memoria de esos sucesivos «yoes» que dejan su marca desde la infancia, terminan por ser una sucesión de lugares que parecen evitar la muerte por cuanto pueden sobrevivir al autor, tanto físicamente como en su propia escritura, en su expresión lingüística. Y, finalmente, el título, como antes explicábamos, suele tener, precisamente, esa dimensión topológica que habla del camino, de la escalera, de la casa... Esta visión de la muerte como una autotanatografía implica contemplar la vida como un suceso de la muerte misma, una descripción del proceso de la muerte, más que 
el de la vida. Ese sería el caso de la obra de Gómez de la Serna, Automoribundia, quien llega a considerar que la propia escritura es una petulancia contra la muerte. Gómez de la Serna no encuentra lo real absoluto en el espacio porque el espacio es sólo una señal de lo real, no lo real mismo: el alero donde cantan los pájaros, el espacio vacío de la plataforma del tren, son señales de realidad, pero no de «lo real». La muerte está detrás de ello, y es muy preciso en textos de Unamuno o Machado.

El espacio de la ciudad pequeña, de las viejas ciudades de Castilla no es sino la oposición a las nuevas ciudades levantadas sobre sus cimientos y la superación de ese espacio nuevo bajo el efecto nostálgico del pasado. No podemos obviar que el trasunto de la muerte en la literatura es, desde el Eclesiastés bíblico, la expresión de la condición fútil de lo real frente a ella.

\section{LA APROPIACIÓN BARROCA DEL ESPACIO POR EL FLÂNEUR}

Cuando Walter Benjamin (1972) escribe acerca de Baudelaire, en su obra El París del segundo imperio en Baudelaire, está definiendo una figura urbanita, la del contemplador íntimo de la ciudad, el escrutador de sus detalles que se sitúa dentro y a distancia de ella. El flâneur es el paseante distraído que deambula mirando todo a su alrededor. El ejemplo que nos propone Benjamin es, evidentemente, Baudelaire. El flâneur experimenta, en muchos casos, la sensación de tedio o de spleen - como le ocurrió al propio Benjamin o a Baudelaire - y tiene la sensación de recoger del entorno urbano una serie de imágenes que no le pertenecen, que van llenando su memoria de un espacio que no le es propio y que le produce una sensación de abandono, una frontera entre el yo y lo otro. «Tengo aún más recuerdos que en mil años de vida», llega a decir Baudelaire en Las flores del mal. El escritor se halla, pues, como una figura que vincula el pasado y el presente. Así lo define:

Su pasión y su profesión es la de desposarse con las multitudes. Para el perfecto vagabundo, para el observador apasionado hay un inmenso goce que consiste en elegir dominio en el número, en lo ondulante, en el movimiento, en lo fugitivo y en lo infinito. Estar fuera de casa y, no obstante, sentirse en casa en cualquier parte [...]. Observador, paseante, filósofo, llamadle como queráis. A veces es poeta; más a menudo se aproxima al novelista o al moralista; es el pintor de circunstancias y de todo cuanto las circunstancias sugieren de eterno (Baudelaire, 2000: 1.379). 
El dominio del espacio se produce porque el mundo en torno se contempla como fuera un espejo, de manera que lo descrito termina siendo la imagen que en él se refleja:

Cabe también compararlo con un espejo, cuyo tamaño es tan inmenso como el de la multitud misma; con un caleidoscopio dotado de conciencia, el cual representa, en cada movimiento, la vida múltiple y la gracia motriz de todos los elementos de la vida. Es un yo insaciable del no-yo, que, a cada instante, lo devuelve y expresa con imágenes más vivas que la propia vida, siempre inestable y fugitiva (Baudelaire, 2000: 1.379-1.380).

En la autobiografía, siempre según Benjamin, la memoria recogería una serie de datos inconexos que el genio artístico reúne y ordena. La voluntad que ordena la infancia, eso es la autobiografía. Luego la escritura del espacio propio no es la pura descripción del lugar, sino la transformación de este por la propia voluntad y la mirada distante y ordenadora del autor. Y hay un motivo evidente para explicar que el arte siempre transforma la realidad y no la refleja de manera aséptica. Todo reflejo artístico de la realidad es memorialístico, «mnemónico», en palabras de Baudelaire. Porque, incluso en la pintura del natural, existe una mínima sucesión temporal que fija el objeto en la memoria para imprimirlo después. Y hay que considerar que el espacio no es un modelo, sino un signo; que el pintor o el escritor o el autobiógrafo no reflejan el espacio urbano -o natural - como un mero decorado, sino como un actor más en la historia narrada.

Al igual que Baudelaire, Benjamin gusta de los lugares urbanos concretos, fundamentalmente los bazares, los mercadillos... como lugar donde los objetos tienen un valor único e individualizado, donde puede estar a solas rodeado de muchedumbre. Lugares barrocos, donde no hay lugar para el vacío, donde el horror vacui, la sensación de absurdo, se llena por los objetos que son contemplados de manera indolente.

En la autobiografía española podemos encontrar casos significativos. Quizá los dos más cercanos a lo que queremos exponer sean los de Gómez de la Serna y Andrés Trapiello. En el caso de este último, podemos encontrar que las primeras palabras que abren el prólogo de El gato encerrado son precisamente las dedicadas al Rastro madrileño, al que ha dedicado un sinfín de páginas en su voluminosa e interesantísima obra diarística: «Todas las cosas que iban extendiendo sobre la acera parecían oxidadas, chatarra, latón viejo; hasta los libros tenían algo de escombros» (Trapiello, 1998: 9).

Lo que interesa de estas narraciones es descubrir cómo el flâneur tiende a producir un tipo de prosa con propensiones formales autobiográficas y re- 
quiere un «yo» muy poderoso que evita la omnisciencia y sólo aporta su opinión acerca de lo que contempla, una aportación a la narración ficcional y autobiográfica de gran calado.

Para Ernesto Baltar, aquel flâneur es, en realidad, la reivindicación de la mirada y de la perspectiva autónoma del autor sobre el mundo:

Frente a los objetos de consumo propios de la producción en serie, Benjamin como buen coleccionista subraya el valor único casi místico, irrepetible, sentimental, aurático de los objetos de bazar. Esto nos recuerda a las cosas que abarrotan el Rastro: "cosas carnales, entrañables, desgarradoras, clementes, lejanas, cercanas, distintas, cosas reveladoras en su insignificancia, en su llaneza, en su mundanidad, ;maravillosas asociadoras de ideas!» que decía Ramón Gómez de la Serna. El flâneur ama la soledad, pero la quiere y la busca en la multitud: de cosas, de imágenes, pero sobre todo de gente (Baltar, 2006: 12).

Esta figura, en nuestra autobiografía contemporánea, también ha dado sus frutos. Está vinculada a la concepción burguesa y a la bohemia de los autores de la primera mitad del siglo XX. Lo observamos en no pocas obras como las memorias de Baroja, las de Cansinos-Asséns, las del propio Gómez de la Serna, pero ha llegado a nuestros días también gracias a los diarios de Trapiello. Y todo ello es impensable sin el concepto nuevo de ciudad. Explica Álvaro Salvador (2007: 22) cómo esta actitud moral y vital está presente en la construcción de los nuevos espacios artísticos, como modelo o como motivo de rechazo. La sociedad burguesa y urbana habría encargado a los escritores que fuesen los cronistas de ese desvanecimiento del régimen antiguo de la ciudad vinculada al campo y del nacimiento del nuevo espacio urbano, de manera que la propia vida del escritor fuera, en sí misma, el reflejo de ese nuevo espíritu del espacio. Así lo explica Álvaro Salvador (2007: 127) con la figura de Gutiérrez Nájera: «He salido a flanear un rato por las calles, y en todas partes, el olor fresco a lama, el bullicio y el ruido de las plazas y la eterna alharaca de los pitos...». O Belem Clark, quien trata de explicar esta delegación de la crónica urbana en los escritores del momento:

Las necesidades del público determinaron en buena medida la orientación de las publicaciones, en una ciudad cuya población iba en considerable crecimiento, que comenzaba a despertar al desarrollo económico y a verse transformada por vías de comunicación, es decir, «que cambiaba constantemente», que necesitaba descubrirse, reconocerse, describirse e informarse, y que, por lo mismo, otorgó esa función a los escritores (Clark, 1998: 36). 
Claro está, que ese público burgués se mezclará con el viejo pueblo. Los barrios irán borrando los nuevos bulevares, exponiendo el lujo de la una a los ojos de la otra y viceversa, esto es, creando una cierta e incipiente conciencia de clase que impondrá, igualmente, una conciencia política que también ha de teñir los nuevos textos autobiográficos o de ciertos tintes autobiográficos. Ahí está, por ejemplo el Baudelaire de Los ojos de los pobres, cuando una de aquellas familias de los lugares conquistados por la modernidad se asoma, por vez primera, a una lujosa cafetería:

No sólo me había enternecido ante aquella familia de ojos, sino que además sentía cierta vergüenza por nuestros vasos y garrafas, mayores que nuestra sed. Volví la mirada hacia la vuestra, mi querido amor, para leer en ella mi pensamiento (Baudelaire, 2000: 600).

Marshall Berman (1988), en su interesante obra Todo lo sólido se desvanece en el aire. La experiencia de la modernidad ${ }^{1}$, explica cómo fue el propio Baudelaire quien abrió los ojos a buena parte de los habitantes de París a la contemplación de la modernidad, fundamentalmente a través de su ensayo El pintor de la vida moderna:

Los bulevares, al abrir grandes huecos a través de los vecindarios más pobres, permitieron a los pobres pasar por esos huecos y salir de sus barrios asolados, descubrir por primera vez la apariencia del resto de su ciudad y del resto de la vida. Y, al mismo tiempo que ven, son vistos: la visión, la epifanía, es en ambos sentidos (Berman, 1988: 153).

Y, aunque esta sea la expresión de lo moderno, encierra, empero, una dualidad aparentemente paradójica: también los viejos maestros tienen su propia modernidad, con lo cual lo moderno no es sólo lo contemporáneo. Por un lado, lo moderno será lo burgués, los bulevares, los desfiles de moda; pero por otro, es el artista el que no participa del ambiente burgués. Esta dualidad es la que produce la mirada ajena a la ciudad, que contempla, precisamente, esos bulevares burgueses que comienzan a surgir en París.

Es decir, la imagen de la ciudad se populariza, no se democratiza. Y la influencia que esto va a producir en el arte cambiará para siempre la imagen previa. Ya nada podrá mirarse con ojos inocentes, ni por uno ni por otro lado.

Y, por cuanto la mirada se politiza y atiende a descubrir la belleza de lo burgués, también se obliga a lo burgués a volver la vista a la pobreza, lo cual

${ }^{1}$ M. Berman, All that is solid melts into air (New York: Simon \& Schuster, 1982). Utilizamos en este estudio, no la edición inglesa, sino la de Siglo XXI de España Editores (1988). 
dará lugar a una nueva mirada, una mirada triste y culpable. Y, a la vez, un esfuerzo de adaptación al medio que supondrá nuevas cotas de libertad adquirida. Para algunos, porque la aparición de los escritores modernistas que transitan estas novedades urbanas también implica la existencia de escritores «antimodernistas» que buscarán los restos no modernos de las ciudades (afirmando, indirectamente, esa modernidad).

Sólo existe el flâneur en las grandes ciudades, pero la modernidad es ya un concepto extendido que se propaga a las sociedades de media Europa. Esta imagen que aportan los autores de la época, mostrará la dualidad que la ciudad imprime a sus habitantes, entre los que están, distanciados de ella, los escritores del momento, aquellos que construirán su identidad a través de sus textos autobiográficos.

\section{REFERENCIAS BIBLIOGRÁFICAS}

BALTAR, E. (2006). «Aproximación a Walter Benjamin a través de Baudelaire». A Parte Rei. Revista de Filosofía 46, 1-18.

BAL, M. (1997). Narratology. Toronto: University of Toronto Press.

BAROJA, P. (1997). Desde la última vuelta del camino. En Obras Completas, vols. I y II. Barcelona: Círculo de Lectores.

BAUDELAIRE, Ch. (2000). Obras. Madrid: Espasa-Calpe (Biblioteca de Literatura Universal).

BENJAMIN, W. (1972). Iluminaciones II. Madrid: Taurus.

BERMAN, M. (1988). Todo lo que es sólido se desvanece en el aire. La experiencia de la modernidad. Madrid: Siglo XXI de España Editores.

BRYSON, N. (1983). Vision and Painting: The logic of the gaze. London: MacMillan.

CABALLERO BONALD, J. M. (1995). Tiempo de guerras perdidas. La novela de la memoria I. Barcelona: Anagrama.

CLARK DE LARA, B. (1998). Tradición y modernidad en Manuel Gutiérrez Nájera. México: UNAM.

DELIBES, M. (1996). He dicho. Barcelona: Destino.

DURÁN LÓPEZ, F. (1991). «Autobiografía, espacio urbano e identidad del intelectual ilustrado: el caso de Mor de Fuentes». Cuadernos de Ilustración y Romanticismo. Revista del Grupo de Estudios del siglo XVIII 3, 81-97. 
FERNÁNDEZ PRIETO, C. (2005). «La muerte, pulsión autobiográfica». Archipiélago 69, 49-56.

GONZÁLEZ RUANO, C. (1979). Memorias. Mi medio siglo se confiesa a medias. Madrid: Tebas.

KERTESZ, I. (2002). Yo, otro. Barcelona: Acantilado.

MARTÍN ESTUDILLO, L. (2007). La mirada elíptica: el trasfondo barroco de la poesía española contemporánea. Madrid: Visor Libros.

PÉREZ GALDÓS, B. (1975). Recuerdos y memorias. Madrid: Tebas.

RAMÓN Y CAJAL, S. (1939). Mi infancia y juventud. Madrid: Espasa Calpe.

- (1981). Recuerdos de mi vida: 1901-1923. Historia de mi labor científica. Madrid: Alianza.

RIDRUEJO, D. (2007). Casi unas memorias. Barcelona: Península.

RODRÍGUEZ DE LA FLOR, F. (1997). Bibliocasmo. Por una práctica crítica de la lecto-escritura. Valladolid: Junta de Castilla y León.

ROMERA CASTILLO, J. (1992). «Escritura autobiográfica de Miguel Delibes». En Miguel Delibes. El escritor, la obra y el lector, Cristobal Cuevas García, Enrique Baena, Antonio M. Garrido Moraga y Antonio Garrido (eds.), 267-276. Barcelona: Anthropos. [Incluido en su obra, De primera mano. Sobre escritura autobiográfica en España (siglo XX) (Madrid: Visor Libros, 2006, 279-290).]

SALVADOR, Á. (2007). El impuro amor de las ciudades. Madrid: Visor Libros.

SIMMEL, G. (1986). El individuo y la libertad. Ensayos de crítica de la cultura. Barcelona: Península.

TRAPIELLO, A. (1998). El escritor de diarios. Barcelona: Península.

VILLENA, L. A. de (2004). Patria y sexo. Barcelona: Seix-Barral. 